\title{
Strategi Reformasi Administrasi dan Kepemimpinan Strategies Admisnistrative Reforms and Leadership
}

\author{
Ramadhani Haryo Seno ${ }^{\mathrm{a}, 1, *}$ \\ ${ }^{a}$ Fungsional Analis Kebijakan Ahli Pertama, Setjen Kementerian ESDM \\ ${ }^{1}$ dhaniharyo.seno@yahoo.com* \\ * corresponding author
}

ARTICLE INFO

Keywords

Administrative Reform;

Administrative Reform

Strategy;

Leadership

\begin{abstract}
This paper seeks to explain the administration and leadership reform strategy. Administrative reform and leadership are two things that are interrelated and inseparable. Leadership in government requires administrative reform to increase the legitimacy of its government. On the other hand, administrative reform requires commitment and consistency of leadership to ensure its success goals are achieved. Administrative reform is something that is ongoing and sustainable, but without the right administrative reform strategy it is clearly difficult to get the desired results. In other words, the right strategy will determine the success of the implementation of administrative reform. Especially if the implementation of this administrative reform is supported by the commitment of the national leadership all out.
\end{abstract}

\section{PENDAHULUAN}

Pemerintah di seluruh dunia saat ini sering mengusulkan, merancang, dan mengimplementasikan reformasi administrasi karena berbagai alasan. Khusus untuk pemerintah yang baru dilantik. Reformasi administrasi seringkali merupakan hal yang sangat menarik dan tepat untuk meningkatkan legitimasi dan popularitas pemerintahan baru (Kim dan Han, 2015:695). Hal ini sejalan dengan apa yang disampaikan oleh Guo (2017: 358) bahwa reformasi administrasi secara inheren bersifat politis karena keberhasilan reformasi secara langsung terkait dengan legitimasi suatu rezim. Artinya semakin sukses pelaksanaan reformasi administrasi semakin legitimate suatu pemerintahan di mata masyarakat. Di negara sedang berkembang reformasi administrasi dianggap suatu hal yang esensial dalam mengelola pemerintahan karena masalah akut yang di hadapi di negara sedang berkembang (Farazmand, 2002:2). Indonesia sebagai salah satu negara sedang berkembang, menurut laporan World Economic Forum (WEF) mengidentifikasi dua faktor utama menyebabkan daya saing Indonesia tidak mampu bersaing secara maksimal yaitu inefisiensi birokrasi dan korupsi (kelembagaan.ristekdikti.go.id, 4 April 2017).

Selain itu, menurut Institute For Management Development World Competitiveness Center, menyebutkan bahwa masalah inefisiensi birokrasi yang menjadi penyebab sulitnya Indonesia bersaing di tataran global (inews.id, 24 Mei 2018). Dua faktor utama tersebut juga diakui oleh Kementerian Tenaga Kerja Indonesia (Kemenaker) bahwa birokrasi dan korupsi selalu menjadi masalah laten yang dihadapi oleh Indonesia. Dimana dua hal tersebut menyebabkan terhambatnya produktivitas dan daya saing Indonesia (poskotanews.com, 21 Desember 2018). Hal ini pun diperparah dengan citra buruk yang sudah terlanjur melekat secara permanen pada birokrasi Indonesia dimata masyarakat (Rudito, dkk, 2016:112). Belum lagi adanya fakta bahwa 1,6 juta Pegawai Negeri Sipil (PNS) Indonesia yang masih berkapasitas rendah (Kompas, 28/3/2018). Melansir data dari Badan Kepegawaian Negara (BKN) sampai dengan 26 Februari 2019, ada 2.357 birokrat yang berstatus sebagai terpidana kasus korupsi (Kompas, 27/2/2019). Fakta diatas memperlihatkan dua masalah utama yang di hadapi oleh Indonesia, ialah berkaitan dengan korupsi dan birokrasi. Oleh karena itu, reformasi administrasi adalah cara universal untuk membawa perubahan pada sektor publik. Negara tidak akan dapat lagi dipercaya, kecuali melakukan reformasi administrasi (Turner dan Hulme, 1997: 105-106). 
Padahal cara sederhana untuk menekan korupsi ialah bagaimana menetapkan aturan main atau sistem yang baik agar sektor swasta dapat taat kepada birokrasi (Prasojo, 2006; Chalid, 2010). Bagaimanapun sektor swasta pasti akan patuh terhadap pemerintah, untuk itu menciptakan lingkungan birokrasi yang bersih dan tidak mudah terinfiltrasi dari praktik moral hazard menjadi keniscayaan (Wibawa, 2005: 204-206). Lambat laun korupsi akan terkikis dengan sendiriya. Belum lagi bila permasalahan birokrasi dikaitkan dengan iklim investasi yang berdampak pada pertumbuhan ekonomi. Berdasarkan penelitian disertasi yang dilakukan oleh Taufiq Efendi (mantan Menteri PAN-RB) menyebutkan bahwa iklim investasi yang belum tumbuh dan berkembang baik di Indonesia salah satunya disebabkan oleh kendala-kendala birokrasi dalam penyelenggaraan investasi (2013:307). Oleh karena itu, tidak salah menyebutkan bahwa reformasi administrasi adalah cara universal untuk membawa perubahan pada sektor publik. Negara tidak akan dapat lagi dipercaya, kecuali melakukan reformasi administrasi (Turner dan Hulme, 1997: 105-106).

Reformasi administrasi pada hakikatnya ialah upaya untuk mengkoreksi berbagai kelemahan yang menyertai penyelenggaran negara yang selama ini berjalan, yang dalam batas tertentu belum dianggap berhasil atau belum maksimal dalam menjalankan tiga fungsi utama penyelenggaraan negara yaitu: fungsi pelayanan, fungsi pemberdayaan, dan fungsi pembangunan serta berfokus pada upaya perbaikan sistem manajemen dan birokrasi (Rasyid, 2013:6-7). Dalam konteks Indonesia, pelaksanaan reformasi administrasi lebih dikenal dengan menggunakan nomenklatur reformasi birokrasi sejak berakhirnya era orde baru tahun 1998. Reformasi birokrasi dalam konteks ini berjalan beriringan dengan reformasi hukum, politik, dan militer. Namun setelah dua dekade berlalu reformasi birokrasi lah yang paling lambat bergerak menuju perbaikan diantara reformasi yang lain (Zuhro, 2014:87). Landasan yuridis formal dalam pelaksanaan reformasi sudah diatur pada tahun 2010 melalui Peraturan Presiden Nomor 81 Tahun 2010 tentang Grand Design Reformasi Birokrasi (GDRB) Tahun 2010-2025. GDRB 2010-2025 merupakan rancangan induk yang berisi arah kebijaksanaan pelaksanaan reformasi birokrasi nasional yang berproses dan terencana. Dimana dalam setiap penyusunan Rencana Pembangunan Jangka Menengah Nasional (RPJMN) dalam setiap lima tahunan, reformasi birokrasi menjadi sasaran pembangunan yang disesuaikan dengan GDRB 2010-2025 (Komarudin, 2014:7).

Menurut Thoha (2011: 106-107), ada empat faktor yang bisa mendorong timbulnya refomasi birokrasi pemerintah yaitu (1) adanya kebutuhan melakukan perubahan dan pembaharuan. (2) memahami perubahan yang terjadi dilingkungan strategis nasional. (3) memahami perubahan yang terjadi di lingkungan strategis global, dan (4) memahami perubahan yang terjadi dalam paradigma manajemen pemerintahan. Pada poin (1) di atas poin yang utama menunjukan bahwa adanya kebutuhan dalam melakukan perubahan dan pembaharuan aparatur negara dan pemerintahan itu sangat tergantung dari kebutuhan pimpinan nasional kita. Jika pimpinan politik nasional kita merasa butuh melakukan perubahan pasti perubahan dan pembaharuan aparatur itu akan terwujud. Dengan kata lain pollitical will dan pollitical commitment dari pimpinan nasional merupakan pintu awal dari faktor pendorong dalam menimbulkan reformasi birokrasi. Pencapaian reformasi birokrasi tentu sangat berkaitan erat dengan kepemimpinan nasional. Tentunya kepemimpinan nasional dilihat dalam konteks pimpinan di lembaga tinggi negara baik itu lembaga tinggi ekskutif, legislatif, dan yudikatif. Kepemimpinan nasional harus mencirikan sebagai orang pemimpin perubahan. Seorang pemimpin perubahan harus memiliki pola pikir yang benar, bukan melanggengkan kemapanan.

Pemimpin tersebut harus meyakini bahwa tugas dasarnya ialah bagaimana melakukan perbaikan secara terus menerus (Dwiyanto, 2016:148). Artinya kepemimpinan nasional yang berciri sebagai pemimpin perubahan dalam upaya mereformasi administrasi yang berjalan haruslah memiliki dua modal dasar yaitu komitmen dan kapasitas. Dua modal dasar ini merupakan hal penting dalam memformulasikan atau merevisi ulang kebijakan yang sudah ada kenapa belum berjalan dengan optimal. Paling tidak pemimpin nasional diharapkan memiliki kemampuan dalam menetapkan sasaran-sasaran yang hendak dicapai terkait pelaksanaan reformasi administrasi (Damanhuri, 2006: 18). Bahkan hasil kajian Prasajo dan Holidin (2018:77) menyimpulkan bahwa kemajuan reformasi administrasi sangat ditentukan oleh kepemimpinan dan kapasitas kelembagaan. 
Oleh karena itu, kepemimpinan merupakan faktor yang sangat strategis dalam mewujudkan pencapaian reformasi administrasi dalam menciptakan sistem yang baik lewat kebijakan publik yang unggul. Dengan demikian bahwa upaya reformasi administrasi sejatinya memang membutuhkan pollitical commitment and pollitical will dari seluruh elite pemerintahan tanpa kehadiran itu maka menjadi mustahil untuk berhasil (Sedarmayanti, 2009; Prasojo, 2009; Kasim, 2011; Rasyid, 2013; Maksum, 2014; Dwiyanto, 2015 dan 2016). Selain itu, dukungan politis dan konsistensi (usaha jangka panjang) pada tataran elite dalam menciptakan mendorong reformasi administrasi juga menjadi faktor penting tercapainya tujuan reformasi administrasi (Juwono, 2018:48).

\section{PEMBAHASAN}

\section{Reformasi Administrasi: Definisi dan Tujuan}

Ada begitu banyak makna dari teori reformasi administrasi bila merujuk berbagai pendapat ahli, dimana mempunyai fungsi yang tidak tunggal, sehingga sebenarnya tidak ada definisi yang dapat diterima secara seragam (Mariana, dkk, 2010:10). Namun pada dasarnya reformasi administrasi berkaitan dengan upaya membangun pemerintahan agar benar-benar untuk memenuhi tujuannya, yakni mewujudkan kehidupan rakyat yang sejahtera, adil, dan bermartabat (Hamdi dan Khairi, 2014:76). Untuk dapat memahami teori reformasi administrasi sebenarnya dapat ditelisik pada dekade 1960an akhir. Tahun 1968 seminar yang diselenggarakan oleh Eastern Regional Organization For Public Administration (EROPA) di Kuala Lumpur, telah menyepakati bahwa reformasi administrasi dilihat secara luas baik itu perubahan mind set and culture set para birokrat maupun perubahan struktur dan fungsi suatu organisasi (dalam Haning, 2015:18). Hal ini sejalan dengan apa yang dikatakan oleh Hahn Been Lee (1968:3) ialah there was a genuine from the very beginning of the seminar on what we realy men change of names and structure of some administrative organization. Rather; it meant changing the behavior of those involved. Sejalan dengan itu Khan (1981) mengatakan bahwa reformasi administrasi sebagai changing established bureacratic practices, behaviours and structure (dalam Turner dan Hulme, 1997:106). Hahn Been Lee dan Khan menekankan perubahan perilaku birokasi merupakan hal yang tidak dapat dipisahkan dari reformasi administrasi. Dengan kata lain reformasi administrasi meliputi aspek institusional dan aspek perilaku juga.

Sementara itu Caiden (1969:8) mengatakan administrative reform sebagai the artificial inducement of administrative transformation againts resistence,yang dapat diartikan beberapa konsekuensi. Pertama, reformasi administrasi merupakan suatu proses kegiatan yang secara sengaja diciptakan oleh manusia, tidak bersifat serampangan atau sewaktu-waktu, baik itu otomatis maupun alamiah, dan dilaksanakan secara sadar. Hal ini berarti setiap perubahan dalam reformasi administrasi sesuatu yang direncanakan. Kedua, reformasi administrasi adalah bagian dari upaya untuk menciptakan pemerintahan yang bersih (perubahan yang fundamental). Ketiga, resistensi beriringan dengan proses reformasi administrasi. Ketiga implikasi itu merupakan tahapan perkembangan reformasi administrasi yang dilakukan dengan proses panjang. Dalam hal ini perubahan yang terencana menandakan adanya persiapan yang menyangkut sumber daya, sistem, instrumen dengan prasyaratnya adalah adanya visi, misi, dan sasaran yang hendak tercapai secara terukur (Maksum, 2010:62). Lebih jauh reformasi administrasi juga diakui Caiden sebagai 'a never ending process'.

Sejalan dengan itu Kasim (1998:11) menyatakan bahwa reformasi administrasi adalah upaya perubahan melalui pendekatan dari atas kebawah (top down) dengan program reorganisasi, perampingan (downsizing), program penghematan biaya, dan program reengginering. Sementara itu Quah (1975) mengambarkan reformasi administrasi dimaknai sebagai suatu proses yang berkelanjutan untuk mengubah struktur ataupun prosedur birokrasi yang terlibat degan maksud untuk meningkatkan efektifitas organisasi dalam mencapai tujuan pembangunan nasional (dalam Nasucha, 2004:43). Mengutip apa yang disampaikan De Guzman dan Reforma (1992) secara lebih komprehensif menyatakan bahwa reformasi administrasi memiliki empat element untuk mendefinisikannya. Pertama, reformasi administrasi perubahan pada birokrasi yang sifatnya sengaja dan terencana. Kedua, reformasi administrasi sama dengan inovasi. Ketiga, efisiensi dan 
efektifitas dalam pelayanan publik adalah keluaran reformasi administrasi. Keempat, urgensitas reformasi terjadi karena adanya ketidakpastian dan perubahan yang cepat pada lingkungan organisasi (dalam Turner dan Hulme, 1997:106). Selain itu Toonen (2003:465) mengatakan bahwa reformasi administrasi membicarakan tentang kualitas administrasi dari sektor publik termasuk dalam pengambilan keputusan kebijakan manajemen sektor publik.

Dari apa yang telah dijelaskan diatas reformasi administrasi kembali menunjukan sebagai suatu proses yang dirancang dengan sengaja, adanya dorongan untuk menjawab perubahan dari ketidakpastian lingkungan sektor publik. Disisi lain, kualitas administrasi terus perlu dilakukan upaya perbaikan dari pembuatan kebijakan dan pengambilan keputusan kebijakan. Sementara itu Quah (2010:128-129) mendefinisikan administrative reform "a deliberate attempt to change both (a) the structure and procedures of the public bureucracy (i.e., reorganization or the institutional aspects and (b) the attitudes and behavior of the public bureucracts involved (i.e., the attitudinal aspects), in order to promet organizational effectiveness and attain national development goals". Artinya ialah sebuah upaya untuk mengubah struktur dan prosedur birokrasi publik serta merubah sikap dan perilaku para pekerja di sektor secara efektif dan efisien yang dilakukan secara sengaja dalam mewujudkan kepentingan nasional. Sementara itu Kim dan Han (2015: 695) menyebutkan bahwa reformasi administrasi sebagai upaya kolektif untuk meningkatkan kinerja pemerintah melalui restrukturisasi organisasi publik dan merevisi ulang proses kebijakan, Dua hal tersebut merupakan slogan atau hal populer dan tantangan yang menakutkan bagi setiap pemerintah di dunia saat ini.

Pada dekade 1980-an sampai saat ini dekade 2010-an muncul terminologi baru yang berkaitan dengan administrative reform yakni public management reform. Bahkan pengertian administrative reform dan public management reform merupakan konsep yang dapat dipakai secara interchangeable namun dapat merujuk pada kultur administrasi publik yang berbeda (Salomo: 2006:73). Menurut Pollit and Bouckaert (2000), reformasi manajemen publik lebih bersifat operasional (praktik), karena dipengaruhi oleh konsep manajemen yang digunakan. Kedua ahli tersebut berpendapat bahwa "Public management reform, defined for our purposes as deliberate change to the structure and process of public sector organizations with the objective of getting them (in some sense) to run better". Barulah setelah itu banyak ahli yang menggunakan penyebutan public management reform untuk menyamakannya dengan istilah administrative reform (Siddique, 2006; Real, 2008; Ongaro dan Valotti, 2008; Webb, 2010; Bhuiyan dan Amogah, 2011; Grosso dan Van Ryzin, 2012: danVries dan Nemec, 2013).

Dari apa yang disampaikan Pollit dan Bouckaert (200) secara jelas diawal menyebutkan bahwa reformasi administrasi merupakan perubahan yang sengaja dilakukan sama hal nya seperti yang disampaikan oleh Caiden (1969) dan Dror (1976). Selain itu dua kategori penting dalam menciptakan organisasi sektor publik yang lebih baik yaitu stuktur dan proses. Pollit dan Bouckaert pun merinci dan memberi contoh secara operasional apa yang dimaksud dengan definisi diatas (2011:2) Dalam hal ini struktur atau proses dilihat dari hal yang bersifat aplikasi dilapangan. Seperti halnya struktur lebih dilihat dari strukur organisasi dari suatu kementerian atau badan atau proses dilihat bagaimana proses birokrasi dalam melakukan perekrutan, pelatihan, promosi jabatan atau pemutusan hubungan kerja, bagaimana melihat hubungan birokrasi dengan warga negara dalam memberikan pelayanan publik dengan struktur kementerian atau badan negara. Sedangkan, bagaimana mendapatkan pemerintahan berjalan lebih baik. Dilihat dari dua hal, apakah organisasi pemerintah lebih efisien dalam memberikan pelayanan publik, memastikan kembali birokrasi lebih responsif dalam memberikan pelayanan. Atau organisasi pemerintahan berfokus untuk lebih baik lagi menjalankan tugas bagaimana mengurangi kemiskinan, meningkatkan ekspor.

Lebih jauh Pollit dan Bouckaert (2011:77) telah memilih lima komponen inti untuk menjawab substansi apa dari reformasi admnistrasi dan tiga komponen inti untuk menjawab bagaimana reformasi administrasi di implementasikan. Kelima komponen inti untuk menjawab substansi apa dari reformasi administrasi ialah keuangan, kepegawaian, organisasi, pengukuran kinerja, dan transparansi/ open governement. Sedangkan bagaimana implementasi dijalankan dapat dijelaskan dalam tiga komponen inti yaitu: top down vs bottom up, peraturan perundangan, dan unit khusus. Dari beberapa pendapat mengenai reformasi administrasi yang dijelaskan oleh beberapa ahli diatas, 
maka Penulis menggunakan pendapat dari Salomo (2006:71-73) hal ini lebih cenderung sesuai dengan konteks Indonesia. Menurutnya reformasi administrasi adalah perubahan yang terjadi dalam sistem administrasi publik yang dilakukan secara sengaja, bersifat fundamental atau radikal, terhadap sejumlah dimensi pemerintahan, mencakup sejumlah aspek dan dapat terjadi pada beberepa tingkatan pemerintahan serta mempunyai tujuan tertentu. Reformasi administrasi mencakup hubungan antara birokrasi dengan masyarakat, serta adanya kebutuhan yang datang dari faktor lingkungan yang terus berubah dan terdapat ketidakpastian.

\section{Upaya Mengoptimalisasikan Pencapaian Reformasi Administrasi: Pemilihan Strategi Reformasi Admnistrasi yang Tepat}

Setelah mengetehaui definisi dan tujuan reformasi administrasi berikutnya adalah merumuskan strategi yang terbaik untuk mencapai tujuan reformasi administrasi. Menurut Mulgan (2009:19) ialah "Public strategy is the systemic use of public resources and powers, by agenices, to achieve public goods" (diartikan penggunaan sumber daya publik dan kekuasaan yang ada secara sistematis oleh badan pemerintahan untuk menciptakan barang-barang publik). Sedangkan menurut, Bastian (2016:9) mengungkapkan bahwa strategi dalam sektor publik (negara) dimaknai sebagai rencana mengenai serangkaian aktivitas mencakup seluruh elemen yang kasat mata maupun yang tidak kasat untuk keberhasilan pencapaian kesejahteraan. Pendapat hampir sama seperti apa yang diungkapkan oleh David dan David (2016:155) bahwa konteks strategi dalam konsep manajemen strategis secara umum dibutuhkan dan secara luas digunakan untuk membuat organisasi pemerintah menjdi lebih efektif dan efisien. Apalagi dalam hal ini reformasi administrasi haruslah merencanakan secara tepat, terukur, dan terarah secara sistemik strategi apa yang digunakan untuk mencapai tujuan reformasi administrasi yang telah ditetapkan. Bukan hal yang tidak mungkin berhasil atau gagalnya reformasi yang dijalankan sangat ditentukan strategi apa yang digunakan.

Lee (1970:14-18) menjelaskan bahwa dalam pelaksanaan reformasi administrasi ada dua strategi yang dapat digunakan yaitu comprehensive strategy dan incremental strategy. Comprehensive strategy dimaknai sebagai suatu cara yang dilakukan oleh suatu badan reformasi tertentu yang berada di pusat kekuasaan yang berfungsi khusus dalam mengendalikan beberapa aspek kegiatan reformasi seperti kepegawaian, anggaran, dan kelembagaan. Sehingga dukungan dari pemimpin ekskutif dalam hal ini presiden atau perdana menteri sangat dibutukan dalam menggunakan comprehensive strategy mengingat dukungan dari legislatif atau partai politik jarang memadai. Oleh karena itu, pollitical will dan pollitical commitment dari ekskutif, legislatif, dan yudikatif menjadi hal penting mengingat seluruh perencananaan reformasi administrasi yang akan diproses dan dimplementasikan harus menjadi perhatian semua pimpinan tinggi negara, sehingga tujuan dari reformasi administasi akan tercapai. Sedangkan, incremental strategy ialah pendekatan strategi yang melihat reformasi adminsitrsi sebagai suatu proses dimana strategi yan dilakukan secara step-by-step (satu demi satu) sehingga nantinya strategi ini membentuk pola langkah yang berurutan. Pendekatan ini mengutamakan pelatihan dari berbagai pihak yang tidak hanya melibatkan staff dari lembaga reformasi, tetapi juga berbagai pihak dari lembaga publik lainnya.

Dror dalam Leemans (1979:48-59) juga membedakan beberapa pendekatan yang saling berlawanan atau adanya polarisasi dalam strategi reformasi administrasi yang akan digunakan, yaitu; strategi struktural versus individu, strategi non collaborative versus colaborative, strategi yang drastis versus piecemeal. Strategi struktul versus individu ialah bahwa para ahli mencoba menjelaskan bahwa permasalahan administrasi sehingga perlu direformasi ialah terletak pada individu dan organisasi. Dalam hal ini pembenahan yang akan dilakukan lebih mendahulukan organisasi dahulu atau individu terlebih dahulu. Strategi non collaborative versus colaborative dapat dijelaskan bahwa setiap pengambilan keputusan reformasi administrasi dapat dilihat dari dua hal. Pada saat keputusan diambil hanya pada satu badan saja yang tertutup, tidak adanya keterlibatan pihak lain diluar pemerintah, dan strategi ini biasanya bersifat memaksa, maka dalam hal ini dinamakan strategi non collaborative. Sedangkan strategi colaborative lebih mengedepankan strategi partispasi dengan seluruh stakeholders dari pemerintah, selain itu merupakan strategi dimana subjek dari reformasi adalah hasil diskusi dengan melibatkan seluruh unit organisasi sampai yang paling rendah. Strategi yang drastic versus piecemeal dapat dijelaskan bahawa strategi mengacu kepada tiga hal besar. Seperti ruang lingkup perubahan bagian dari 
birokrasi yang terkena dampak langsung, baik itu pendekatan yang bersifat mikro, meso, maupun makro. Kedua, intensitas perubahan apakah bersifat fundamental atau marginal. Ketiga, jangka waktu yang telah ditetapkan dalam proses reorganisasi yang telah direncanakan.

Selain itu pendapat lain dari Turner dan Hulme menyatakan ada lima strategi dari reformasi administrasi, yaitu partisipasi, sumber daya manusia, akuntabilitas, restrukturisasi dan kerjasama publik-swasta (1997:108-126). Pertama, restrukturisasi sebagai salah satu strategi dari reformasi administrasi meliputi: menghilangkan red tape, melakukan downsizing, dan mendesentralisasikan kewenangan serta peningkatan daya tanggap organisasi publik pada masyarakat. Kedua, partisipasi yaitu adanya tuntutan agar publik lebih berpartisipasi dalam membentuk aktifitas birokrasi sebagai penyedia layanan agar sesuai dengan yang dibutuhkan dan yang diinginkan oleh publik. Ketiga, pengembangan sumber daya manusia yaitu merupakan strategi penting dalam reformasi administrasi. Fokus utama para aktor reformasi ialah bagaimana menciptakan efektifitas dan efiensiesi birokrasi. Perhatian pada pengembangan sumber daya manusia dapat dilakukan diantaranya ialah melalui seleksi pegawai, penerimaan pegawai, penilaian pegawai, sistem penghargaa terhadap pegawai, dan pengemnagan karir pegawai sehingga peningkatan keahlian dan kapasitas dapat tercermin dalam melaksanakan kegiatan sehari-hari yang lebih efektif dan efisien. Keempat, akuntabilitas merupakan kekuatan yang mendorong setiap aktor kunci reformasi administrasi agar lebih tanggap dan memastikan adanya kinerja yang lebih baik. Kelima,

kerjasama antara pemerintah dan swasta dalam memberikan layanan publik. Dahulu pemerintah sebagai aktor tunggal dalam memberikan pelayanan publik dasar kepada masyarakat seperti kesehatan, pendidikan, dan kependudukan. Melalui reformasi administrasi, diperkenalkan upaya kolaboratif yang melibatkan pemerintah dan lembaga swasta serta organisasi non pemerintah.

Selain itu menurut H. Siedentopf dalam Caiden (1982:XV) ada tiga strategi dari reformasi administrasi, yaitu fiskal, struktural, dan program. Pertama, fiskal yaitu strategi yang digunakan untuk menekan atau mengefisiensikan biaya dan pengeluaran belanja pemerintah sekaligus memelihara pelayanan publik. Strategi fiskal menekankan kepada rasionalisasi dan memoderinasi perubahan struktur internal yang berdampak langsung kepada masyarakat maupun birokrasi itu sendiri. Kedua, struktural yaitu strategi yang berusaha untuk mendorong dan meningkatkan produktivitas dari birokrasi tanpa harus menambah anggaran pengeluaran. Point dari strategi ini ialah pada struktur organisasi (kelembagaan), pengambilan keputusan, prosedur operasional kegiatan, dan profesionalitas dari birokrasi. Ketiga, program yaitu strategi yang berusaha untuk mengoptimalkan pemberian pelayan publik kepada masyarakat yang lebih baik lagi baik dalam kualitas maupun kuantitas, serta objektifitas kegiatan pemerintahan. Strategi yang dilakukan ialah berusaha untuk mengurangi campur tangan pemerintah dan menyederhanakan peraturan pemerintah. Strategi ini juga dijalankan melalui program-program yang dapat meningkatkan efektifitas maupun efisiensi pemerintah dalam pemberian pelayanan kepada masyarakat.

Sementara itu menurut Fesler dan Kettl (1996:80-81) ada tiga strategi dari reformasi administrasi yaitu perampingan, merekayasa ulang, dan perbaikan berkelanjutan dijelaskan bahwa ada tiga strategi utama reformasi administrasi yang dapat diuraikan dalam lima aspek (tujuan, arahan, metodee, fokus strategi, dan tindakan) untuk mencapai tujuan reformasi administrasi. Pertama, perampingan yaitu berusaha dengan menurunkan pengeluaran anggaran pemerintah dengan cara menganalisis ukuran organisasi yang mana bisa disesuaikan (dirampigkan). Hal ini dilakukan sebagai bentuk ketidakpuasaan masyarakat terhadap pemerintah atas pemborosan anggaran yang dilakukan. Untuk menyesuaikan organisasi yang tepat ukuran dapat dilakukan dengan cara mengintervensi strategi program pelayanan yaitu mengecilkan ukuran organisasi yang sudah ada. Artinya menunjukan lebih baik struktur organisasi yang ramping namun kaya fungsi daripada sebaliknya. Kedua, rekayasa ulang yaitu strategi yang berusaha untuk meningkatkan efisiensi organisasi dengan melalukan perbahan yang radikal. Dalam hal ini pimpinan tinggi berusaha mengarahkan perubahan menentukan organisasi akan dibawa kemana, menciptakan kompetisi yang kompetitif antara pegawai dalam memberikan pelayanan kepada masyarakat dan hal tersebut diharapkan dapat mentransformasi organisasi. Ketiga, perbaikan berkelanjutan yaitu strategi yang berusaha untuk lebih responsif terhadap tuntutan kebutuhan masyarakat dengan meningkatkan kualitas pemberian layanan. Lebih mengedepankan terciptanya hubungan 
interpersonal sesama pegawai, ketika hubungan kuat antara pegawai sudah terjalin maka perbaikan akan mudah terlaksana. Strategi ini dibangun dari bawah ke atas atau dari antar pegawai baru menuju ke pimpinan tinggi, sehingga hubungan interpersonal antara pegawai lebih penting dari struktur dan proses dalam organisasi.

Selain itu Osborne dan Plastrik (2000: 44-54) juga mengemukakan lima strategi reformasi. Walaupun konsep yang digunakan oleh Osborne dan Plastrik dalam konteks reinventing government, namun makna yang bisa ditangkap dari pengertian konsep tersebut tidak terlalu berbeda dengan makna dari konsep administrative reform ataupun konsep public sector reform (Kamaruddin, 2017:37). Lima strategi yang dikemukakan ditujukan untuk mewujudkan perubahan birokrasi menuju pemerintahan wirausaha. Strategi tersebut terdiri dari strategi inti, konsekuensi, pelanggan, pengendalian, dan budaya. Pertama, strategi inti merupakan upaya untuk mendiagnosis tujuan dari sistem organisasi pemerintah. Mendiagnosis kembali tujuan pemerintah bertujuan memusatkan perhatian pada fungsi yang seharusnya dilaksanakan dan menghapus fungsi-fungsi yang tidak lagi sesuai untuk dilaksanakan. Kedua, strategi konsekuensi, berkaitan dengan sistem insentif pemerintah. Kondisi yang diharapkan ialah kedepan insentif yang diperoleh harus berdasarkan kinerja individu maupun organisasi. Ketiga, strategi pelanggan melihat aspek penting dari akuntabilitas atau pertanggungajawaban. Strategi ini menjelaskan tentang kepada siapa seharusnya organisasi bertanggung jawab. Keempat, strategi pengendalian atau kontrol yang menentukan letak kekuasaan pengambilan keputusan. Strategi ini menggeser bentuk pengendalian yang digunakan dari aturan-aturan yang rinci serta komando yang hirarkis ke misi bersama dan sistem yang menciptakan akuntabilitas kinerja. Strategi ini memberdayakan pegawai dengan mendorong wewenang pengambilan keputusan, menanggapi pelanggan, dan memecahkan masalah mereka. Kelima, Strategi budaya merupakan bagian penting terakhir dari sistem pemerintah yang menentukan nilai-nilai, norma, sikap, dan harapan pegawai. Aspek budaya sangat dipengaruhi oleh bagian DNA lainnya yaitu tujuan organisasi, sistem insentif, sistem pertanggungjawaban, dan struktur kekuasaan. Oleh karena itu, mengubah budaya bukan persoalan yang mudah. Perlu komitmen yang tinggi dari semua anggota organisasi untuk benar-benar ingin berubah dan mengadopsi budaya baru.

Sedangkan menurut Thoha (2011:109-112) bahwa ada 3 (tiga) strategi dalam upaya pembenahan dalam melakukan reformasi birokrasi yaitu penataan kelembagaan birokrasi pemerintah, penataan sistem birokrasi pemerintah, dan penataan sumber daya aparatur. Pertama, upaya yang dilakukan ialah bagaimana menata kultur dan struktur. Dalam kultur nantinya akan membedakan suatu boundary yang membedakan suatu pemerintahan itu dengan pemerintahan lainnya. Sedangkan stuktur merupaka kerangka yang dipergunakan sebagai aliran tata proses bagaimana kultur itu bisa diterapkan dan diwujudkan dalam suatu pemerintahan. Kedua, dari sistem ini diharapkan visi dan keinginan politik intu menunjang tercapainya sistem yang menciptakan aparatur yang menghargai ditegakkannya hukum, profesional, kompeten, dan akuntabel. Merit sistem lebih dekat ke arah cita-cita tersebut. Ketiga, bagaimana mendorong peningkatan kesejahteraan pegawai, karena keadaan tersebut menjadi tali menali dengan profesionalitas pegawai.

Pemilihan strategi reformasi administrasi pada suatu negara tentunnya harus disesuikan dengan kondisi atau pengaruh dari hal mana yang menjadi prioritas untuk dibenahi. Apakah sumber daya manusia terlebih dahulu atau organisasinya terlebih dahulu serta perangkat sistemnya. langkah apapun yang akan ditempuh sangat dipengaruhi dengan lingkungan ekonomi, politik, sosial, budaya, hukum, dan teknologi. Hal ini menjadi penting untuk disesuaikan agar strategi yang digunakan dapat efektif dan efisien dalam pelaksanaannya. Dari berbagai macam strategi reformasi administrasi yang telah diurakan diatas peran pemimpin lah yang pada prinsipnya akan menentukan mana kira-kira strategi yang tepat untuk diimpelementasikan. Determinan implementasi reformasi salah satunya ditentukan dari peran kepemimpinan yang dijalankan (Kamaruddin, 2017:386). Strategi pada dasarnya hanyalah alat untuk mencapai tujuan, bagaimana alat itu dapat optimal saat digunakan tergantung dari bagaimana alat itu digunakan dan dalam lingkungan seperti apa saat digunakan. Tugas pemimpin lah yang memastikan bagaimana alat itu tepat dan optimal saat 
digunakan. Oleh karena itu, peran strategis pemimpin sangat dinantikan lewat komitmen dan konsistensinya dalam menentukan dan menjalankan strategi reformasi administrasi.

\section{KESIMPULAN}

Dari pemaparan di atas tentang reformasi administrasi terutama berkaitan dengan strategi reformasi menunjukan bahwa ada prasyarat mutlak untuk mencapai kesuksesan. Prasayarat mutlak itu ialah pollitical commitment and pollitical will dari seluruh elite pemerintahan tanpa kehadiran itu maka menjadi mustahil untuk berhasil (Sedarmayanti, 2009; Prasojo, 2009; Kasim, 2011; Rasyid, 2013; Maksum, 2014; Dwiyanto, 2015\&2016). Selain itu dukungan politis dan konsistensi (usaha jangka panjang) pada tataran elite dalam menciptakan mendorong reformasi administrasi juga menjadi faktor penentu tercapainya tujuan reformasi administrasi (Juwono, 2018:48). Dengan demikian ketika kita berbicara reformasi adminitrasi dalam konteks Indonesia ialah bagaimana menghadirkan dukungan atau komitmen serta konsistensi dari pemimpin nasional maupun kelompok elite. Hal itulah yang menjadi hulu, kenapa reformasi administrasi yang sudah dijalankan Indonesia belum mendapatkan hasil yang kita inginkan. Dimana hilir atau muara dari reformasi administrasi ialah pada dasarnya bagaimana menciptakan negara Indonesia yang demokratis dan sejahtera. Untuk apa demokratis namun kesejahteraan belum terwujud. Kesejahteraanlah yang menjadi pangkal dari tujuan reformasi administrasi itu dilakukan.

\section{DAFTAR PUSTAKA}

[1]. Bastian, Indra. (2016). Strategi Manajemen Sektor Publik. Jakarta: Salemba Empat.

[2]. Bhuiyan, Shahjahan H dan Francis Amagoh. (2011). "Public sector reform in kazahstan: issues and perspective". International Journal of Public Sector Management. Vol 24 Issue: 3. Page 227-249.

[3]. Caiden, Gerald E. (1969). Administrative Reform. London: Allen Lane The Penguin Press.

[4]. Chalid, Hamid. (Eds). (2010). Reformasi Birokrasi Peta Masalah dan Alternatif Solusi. Jakarta: Masyarakat Transparansi Indonesia.

[5]. Damanhuri, Didin S. (2006). Korupsi, Reformasi Birokrasi \& Masa Depan Ekonomi Indonesia. Jakarta: LPFE Universitas Indonesia

[6]. David, Fred R. dan Forest R. David. (2016). Manajemen Strategi: Suatu Pendekatan Keunggulan Bersaing-Konsep. (Terj). Novita Puspasari dan Liza N. Puspitasasri. Edisi Kelima Belas. Jakarta: Salemba Empat

[7]. Dwiyanto, Agus. (2015). Reformasi Birokrasi Kontekstual Kembali Ke Jalur Yang Benar. Yogyakarta: Gajah Mada University Press.

[8]. Dwiyanto, Agus. (2016). Memimpin Perubahan di Birokrasi Pemerintahan Catatan Kritis Seorang Akademisi. Yogyakarta: Gajah Mada University Press.

[9]. Dror. Yehezkel. (1976). "Strategies For Administrative Reform", dalam AF Leemans, ed, The Management of Change In Government. The Hague: Martinus Nijhoff

[10]. Eastern Regional Organization For Public Administraion (EROPA), Seminar on Administrative Reform and Innovations, Vol.2: (Kuala Lumpur, Juni 1968).

[11]. Effendi, Taufiq. (2013). Reformasi Birokrasi dan Iklim Investasi. Jakarta: Konstitusi Press.

[12]. Farazmand, Ali. (Eds). (2002). Administrative Reform in Developing Nations. Westport: Praeger Publisher.

[13]. Fesler, James W dan Donald F Kettl. (1996). The Politics of The Administrative Process. Second Edition. New Jersey: Chatham House Publishers Inc.

[14]. Hamdi, Muchlis dan Halilul Khairi. (2014). "Reformasi Birokrasi: Menuju Peningkatan Pelayanan Publik, dalam Jurnal Ilmu Pemerintahan Edisi 45, Agustus 2014.

[15]. Haning, Mohamad Tharir. (2015). Reformasi Birokrasi: Desain Organisasi yang Mendukung Pelayanan Publik di Indonesia. Yogyakarta: Ilmu Giri.

[16]. Guo, Baogang. (2017). "China's Administrative Governance Reform in the Era of "New Normal". Journal of Chinese of Political Science. Vol 22. Page 357-373.

[17]. Grosso, Ashley L dan Gregg G Van Ryzin. (2012). Public management reform and citizen perceptions of the UK Health System. International Review of Administrative Sciences. Vol 78 Issue: 3. Page 494513.

[18]. Juwono, Vishnu. (2018). Melawan Korupsi Sejarah Pemberantasan Korupsi di Indonesia 1945-2014. Jakarta: Kepustakaan Populer Gramedia. 
[19]. Kasim, Azhar. (1998). Reformasi Administrasi Negara sebagai Prasyarat Upaya Peningkatan Daya Saing Nasional. Pidato Pengukuhan Guru Besar, FISIP-Universitas Indonesia. Jakarta: FISIPUniversitas Indonesia. Jakarta, 21 Maret 1998.

[20]. Kasim, Azhar. (2011). "Kerangka Dynamics Governance Bagi Reformasi Administrasi Negara". Jurnal Ilmu Administrasi Negara dan Manajemen Publik. Vol 1. No.1. Hal.7-13.

[21]. Kamaruddin. (2017). Determinan Keberhasilan Implementasi Reformasi Administrasi Pada Lembaga Administrasi Negara Periode 2012-2014. Disertasi: FISIP Universitas Indonesia, Jakarta.

[22]. Kim, Sunhyuk dan Chonghee Han. (2015). "Administrative reform in South Korea: New Public Management and the bureaucracy". International of Administrative Science. Vol 8. Issue: 4. Page: $694-$ 712.

[23]. Komarudin. (2014). Reformasi Birokrasi dan Pelayanan Publik. Jakarta: Genesido.

[24]. Leemans, Arne F. (1976). "Overview", dalam AF Leemans, ed, The Management of Change In Government. The Hague: Martinus Nijhoff.

[25]. Lee, Hahn Been (1970). "The Concept, Structure and Strategy of Administrative Reform: An Introduction", dalam Hahn Been Lee dan Abelrado G Samonte, ed, Administrative Reform in Asia. Manila: The Eastern Regional Organization For Public Administraion (EROPA).

[26]. Lee, Hahn Been. (1976). "Bureaucratic Models And Administrative Reform", dalam AF Leemans, ed, The Management of Change In Government. The Hague: Martinus Nijhoff.

[27]. Maksum, Irfan Ridwan. (2010). Organisasi Negara Amuba: Jalinan Sistemik Administrasi Publik, Reformasi Administrasi dan Pemerintahan Daerah. Depok: Departemen Ilmu Administrasi-FISIP UI.

[28]. Maksum, Irfan Ridwan. (2014). "Strategi Reformasi dalam Pemerintahan Republik Indonesia". Jurnal Ilmu Pemerintahan: Reformasi Birokrasi. Edisi 45. Hal:59-69.

[29]. Mariana, Dede, dkk. (2010). "Reformasi Birokasi dan Paradigma Baru Administrasi Publik di Indonesia", dalam Falih Suaedi dan Bintoro Wardiyanto, ed, Revitalisasi Administrasi Negara Reformasi Birokrasi dan E-Governancce. Yogyakarta: Graha Ilmu.

[30]. Mulgan, Geoff. (2009). The Artof Public Strategy: Mobilizing, Power, and Knowledge for The Common Good. New York: Oxford University Press.

[31]. Nasucha, Chaizi. (2004). Reformasi Administrasi Publik Teori dan Praktik. Jakarta: Grasindo.

[32]. Osborne, David dan P. Plastrik. (2000). Memangkas Birokrasi: Lima Strategi Menuju Pemerintahan Wirausaha. (Terj). A. Rosyid dan Ramelan. Cetakan Kedua. Jakarta: PPM Manajemen.

[33]. Ongaro, Edoardo dan Giovanni Valotti. (2008). "Public management in italy: explaining the implementation gap". International Journal of Public Sector Management. Vol. 21. Issue: 2. Page 174204.

[34]. Pollit, Christopher dan Geert Bouckaert. (2000). Public Management Reform: A Comparative Analysis Oxford: Oxford University Press.

[35]. Pollit, Christopher dan Geert Bouckaert. (2011). Public Management Reform: A Comparative Analysis New Public Management, Governance, and The Neo Weberian State. Third Edition. Oxford: Oxford University Press.

[36]. Prasojo, Eko. (2006). "Reformasi Birokrasi di Indonesia: Beberapa Catatan Kritis". Jurnal Bisnis dan Birokrasi. Vol. XIV. No. 1. Hal 295-304.

[37]. Prasojo, Eko. (2009). Reformasi Kedua Melanjutkan Estafet Reformasi. Jakarta: Salemba Humanika.

[38]. Prasojo, Eko dan Defny Holidin. (2018). "Leadership and Public Sector Reform in Indonesia" dalam Evan Berman dan Eko Prasojo, ed, Leadership and Public Sector Reform in Asia. London: Emerald Publishing Limited.

[39]. Rasyid, M. Ryaas. (2013). "Membangun Pemerintahan Yang Baik Melalui Reformasi Administrasi dan Birokrasi”, dalam Adriana Elisabeth, dkk, ed, Evaluasi Reformasi Birokrasi Di Indonesia. Jakarta: AIPI.

[40]. Rosidi, Ajip. (2015). Korupsi dan Kebudayaan. Cet-3. Bandung: Dunia Pustaka Jaya.

[41]. Real, Isabel Corte. (2008). "Public management reform in portugal. successess and failure". International Journal of Public Sector Management. Vol. 21 Issues: 2. Page: 205-229.

[42]. Quah, Jon S.Tien. (2010). Public Administration Singapore Style. United Kingdom:Emerald Group Publishing Limited. The Florida State University, USA

[43]. Salomo, Roy Valiant. (2006). Scenario Planinng Reformasi Administrasi Pemerintah Subnasional di Indonesia: Sebuah Grand Strategy Menuju Tahun 2025. Disertasi: FISIP Universitas Indonesia, Jakarta.

[44]. Siddiquee, Noore Alam. (2006). "Public management reform in malaysia: recent initiatives and experience". International Journal of Public Sector Management. Vol 19. Issue: 4. Page: 339-358.

[45]. Sedarmayanti. (2009). Reformasi Administrasi Publik, Reformasi Birokrasi, dan Kepemimpinan Masa Depan (Mewujudkan Pelayanan Prima dan Kepemerintahan yang Baik). Bandung: Refika Aditama.

[46]. Thoha, Miftah. (2011). Birokrasi Pemerintah Indonesia di Era Reformasi. Cet-3. Jakarta: Kencana. 
[47]. Toonen, Theo A.J. (2003). ”Administrative Reform, dalam B Guy Peters dan Jon Pierre, ed, Handbook of Public Administration. California: Sage Publication.

[48]. Turner Mark dan David Hulme. (1997). Governance, Administration, and Development: Making the State Work. London: Macmillan Press Ltd.

[49]. Vries, Michiel De dan Juraj Nemec. (2013). "Public sector reform: an overview of recent literature and research on NPM and alternative paths". International Journal of Public Sector Management. Vol. 26 Issue: 1. Page: 4-16.

[50]. Webb, Werner. (2010). "Public management reform and the management of ethics: incompatible ideals for the developing state". International Journal of Public Sector Management. Vol. 23. Issue: 7. Page: 669-684.

[51]. WEF (World Economic Forum). (2013). The Global Competitiveness Report 2013-2014. Geneva: World Economic Forum.

[52]. WEF (World Economic Forum). (2014). The Global Competitiveness Report 2014-2015. Geneva: World Economic Forum.

[53]. WEF (World Economic Forum). (2015). The Global Competitiveness Report 2015-2016. Geneva: World Economic Forum.

[54]. WEF (World Economic Forum). (2016). The Global Competitiveness Report 2016-2017. Geneva: World Economic Forum.

[55]. WEF (World Economic Forum). (2017). The Global Competitiveness Report 2017-2018. Geneva: World Economic Forum.

[56]. Wibawa, Samodra. (2005). Reformasi Administrasi (Bunga Rampai Pemikiran Administrasi Negara atau Publik). Yogyakarta: Gava Media.

[57]. World Bank (2018), Worldwide Governance Indicators online database, available at http://info.worldbank.org/governance/wgi/index.aspx\#home.

[58]. Zuhro, R. Siti (2014). "Birokrasi, Demokrasi, dan Politik di Indonesia, dalam Jurnal Ilmu Pemerintahan Edisi 45, Agustus 2014.

\section{Sumber Website dan Surat Kabar:}

[1]. https://kelembagaan.ristekdikti.go.id/index.php/2017/04/11/memperbaiki-daya-saing-indonesia/ diakses pada tanggal 13 Maret 2019 pukul 09.08 WIB.

[2]. https://www.inews.id/finance/makro/ini-penyebab-peringkat-daya-saing-indonesia-turun/133025 diakses pada tanggal 13 Maret 2019 pukul 09.15 WIB.

[3]. http://poskotanews.com/2018/12/21/kemnaker-korupsi-dan-birokrasi-hambat-daya-saing-nasional/ diakses pada tanggal 13 Maret 2019 pukul 09.20 WIB.

[4]. https://www.cnnindonesia.com/ekonomi/20190104192143-85-358599/pnbp-sektor-esdm-lampauitarget-tembus-rp2175-triliun diakses pada tanggal 13 Maret 2019 Pukul 10.00 WIB.

[5]. WEF (World Economic Forum). (2016). The Global Competitiveness Report 2016-2017. Geneva: World Economic Forum.

[6]. WEF (World Economic Forum). (2017). The Global Competitiveness Report 2017-2018. Geneva: World Economic Forum. 